\title{
A MÉLTÁNYOSSÁG ÉS AZ INTÉZMÉNYI BIZALOM SZEREPE A GAZDASÁGBAN
}

\section{FAIRNESS AND INSTITUTIONAL TRUST IN ECONOMY}

\author{
Boda Zsolt \\ PhD, tudományos tanácsadó, MTA Társadalomtudományi Kutatóközpont Politikatudományi Intézet \\ egyetemi docens, Budapesti Corvinus Egyetem \\ boda.zsolt@tk.mta.hu
}

\begin{abstract}
ÖSSZEFOGLALÁS
A tanulmány az intézmények iránti bizalom gyökereiről és következményeiről szól. A szakirodalom általában magától értetődő módon tételezi, hogy a bizalom pozitív értéktartalmú jelenség; míg a hazai szakirodalom többnyire hazánk gyenge bizalmi kultúráját és ennek káros következményeit emeli ki. A tanulmány egyfelől elfogadja ezeket az állításokat, és amellett érvel, hogy a bizalom lényegét tekintve morális jelenség, és normatív alapokra épül, amelyeken belül az eljárási méltányosság kiemelt jelentőségűnek tűnik. A hazai és a nemzetközi szakirodalom alapján szisztematikusan áttekinti az intézményi bizalom gyakorlati jelentőségét, és a magyar helyzet megértéséhez is további adalékokkal szolgál. Másfelöl a tanulmány arra is rámutat, hogy a bizalom nem szükségképpen morális jelenség: megfelelő erkölcsi alapok nélkül is kiváltható. Az érzelmeket, az azonosulás érzetét mozgósító, vagy a mélyebb értékkonfliktusokat a fair eljárásokkal mintegy elfedő taktikák képesek lehetnek a bizalmat növelni. Mindez nemcsak a politikai kommunikáció, de a vállalati PR-nak is sajátja. Valószínűsíthető, hogy az ilyen bizalom törékeny, és hosszabb távon erodálódik, de közben komoly károkat okozhat. A cél az, hogy a bizalom áldásai a szükséges morális feltételek megléte mellett érvényesüljenek.
\end{abstract}

\section{ABSTRACT}

The paper focuses on trust in institutions, its roots and practical consequences. The literature on trust assumes that it is a phenomenon with positive value content, while Hungarian studies typically emphasise the low level of public confidence and its negative consequences. The paper accepts these theses, and argues that trust is essentially a moral phenomenon, built on normative expectations - and among them procedural fairness seems to be of high importance. Referring to both Hungarian and international research the paper overviews the consequences of trust and provides further evidences on the Hungarian situation. However, the paper also argues that trust is not necessarily ethical, as it might be triggered without the proper normative grounds. Activating emotions, identification or using fair procedures only to cover deeper value conflicts may build trust, as both political communication and corporate PR sometimes illustrate the point. This kind of trust is probably more fragile and doomed to erode over time, however, it still can cause considerable harm. The objective can only be that the positive effects of trust prevail in the presence of necessary moral conditions. 
Kulcsszavak: intézményi bizalom, eljárási méltányosság, együttműködés

Keywords: institutional trust, procedural fairness, cooperation

A bizalom kutatása több évtizedes múltra tekint vissza a társadalomtudományokban - az irodalom túlnyomó része azonban a személyek közötti bizalommal foglalkozik. Az intézmények iránti bizalom, annak gyökerei és gyakorlati következményei nem kaptak még a jelentőségüknek megfelelő figyelmet.

A tanulmány célja kettős. Egyrészt hazai és nemzetközi empirikus kutatások alapján igyekszik bemutatni az intézményi bizalom gyakorlati jelentőségét, túlmenve a jól ismert megfontoláson, miszerint a bizalom stabilizálja az intézményi, szervezeti kapcsolatokat, és ezáltal csökkenti a tranzakciós költségeket. Másrészt amellett érvel, hogy a bizalom alapvetően morális erőforrás, amelynek etikai alapjai vannak - a kutatások alapján az eljárási méltányosság elvei kiemelt jelentőségüek e tekintetben. A bizalom továbbá ,vakká”, kritikátlanná is válhat, és ezáltal a gyakorlati jelentőségének előjele is pozitívból negatívba fordulhat. Vagyis, megfelelö morális alapok nélkül a bizalom értéke elvész.

Bizalom alatt azt a várakozást értjük, amely szerint a bizalom tárgya (személy vagy intézmény) az elvárt, illetve elvárható módon fog viselkedni egy adott helyzetben. A bizalom tehát az egyén attitudinális jellemzője, amely a jövővel kapcsolatos várakozást fejez ki. A bizalom magyarázatának és társadalmi jelentőségének könyvtárnyi irodalma van, ami jelzi a fontosságát, valamint a fogalom összetettségét is. A bizalommal kapcsolatos nehézség abból fakad, hogy szerteágazó gyökerei vannak, és különféle módokon nyilvánulhat meg.

A bizalom és a bizalmatlanság részben racionális jelenség (vö. Hardin, 1998), amennyiben korábbi tapasztalatok vagy megbízható információk alapján jó okunk lehet megbízni vagy éppen nem megbízni valakiben. Ugyanakkor tagadhatatlan, hogy a bizalomnak érzelmi alapjai is vannak: a pozitív érzelmek növelik, a negatív érzelmek pedig csökkentik a bizalmat, akár „irracionális” módon is. A bizalom értékelő attitüdökre is támaszkodik: a helytelennek, etikátlannak ítélt magatartás aláássa a bizalmat.

\section{AZ INTÉZMÉNYI BIZALOM JELENTŐSÉGE}

A bizalom gyakorlati jelentősége abban áll, hogy segíti az együttmüködést. Ezt hangsúlyozza Francis Fukuyama is sokat idézett könyvében, amikor pozitív öszszefüggést talál a bizalom szintje és a gazdasági szervezetek mérete között. Az alacsony bizalomszintü országokban a vállalatok tipikusan a családok irányítása alatt maradnak, míg a magasabb bizalomszint lehetővé teszi az együttmükö- 
dést idegen szereplők között is, így professzionális menedzser foglalkoztatását és a vállalatméret növelését (Fukuyama, 1997). Tulajdonképpen az együttmüködési készség erősítéséből ered a bizalom ama sokat emlegetett haszna is, hogy kiszámíthatóságot teremt, stabilizálja az interakciókat, és ezáltal csökkenti a tranzakciós költségeket. A gyakran hivatkozott klasszikus példa az antwerpeni gyémántpiac, ahol nagy értékü üzletek köttetnek meglepően alacsony szintü formalizáltság mellett.

Kérdés persze, hogy a pozitív hatások a bizalomból erednek-e, avagy azokból a tényezőkből, amelyek létrehozzák a bizalom és a megbízhatóság jelenségeit. Valójában mindkettőből, ugyanis a bizalomra méltóság magában foglalja a bizalmat is: abban inkább tudunk bízni, aki bennünk is bízik. A bizalom pozitív visszacsatolását szemlélteti a „Tit for tat” stratégiai sikeressége is a fogolydilemma-típusú döntési helyzetek megoldásában. Ugyanakkor a bizalom azon morális minőségek indikátoraként is értelmezhető, amelyek elősegítik a bizalmi viszony és az együttmüködés létrejöttét.

A bizalom morális alapjaira később térünk ki, de fontos megjegyezni, hogy ezek valóban csak elősegítik a bizalom létrejöttét, szigorú értelemben se nem szükséges, se nem elégséges feltételei annak. Egyrészt a bizalom létrejöhet megfelelő morális előfeltételek teljesülése nélkül is. Ezt nevezhetjük „,vak” vagy kritikátlan, naiv bizalomnak is; de bizonyos helyzetekben a szereplöknek nincs más választásuk, mint a bizalom: ilyen a szélsőségesen kiszolgáltatott helyzet (például a gyermek viszonya a szüleihez). A „,vak bizalom” esetei mutatják, hogy a bizalom nem feltétlenül morális érték: néha éppen a bizalmatlanság a morálisan igazolható, értékes viszony. Emellett érvel Russel Hardin (1998) is, de ezt támasztja alá egy kutatásunk is, amelyben azt találtuk, hogy azok az emberek hajlamosak a civil akciók különböző formáiban részt venni, akik közepesen bíznak az intézményekben. Az alacsony bizalomszintủ emberek nem látják értelmét, a magas bizalomszintúek meg nem látják jelentőségét a közügyekbe való beleszólásnak (lásd Boda, 2013). Másrészt a bizalom morális alapjai nem is feltétlenül elegendőek a bizalom megteremtéséhez. A bizalmatlanság kultúrája, a gyanakvó beidegződések meggátolhatják a megbízhatóság jeleinek megfelelő értelmezését, sőt, akár a bizalomra egyébként érdemes aktor kizsákmányolásához is vezethetnek.

\subsection{A döntések támogatása}

A bizalom legitimitást biztosít a döntések, akár az egyén számára kellemetlen következményekkel járó döntések számára. Az autoritás, legyen szó vállalatvezetésről, hatóságról vagy a kormányról, időről időre kénytelen olyan döntéseket hozni, amelyek kellemetlenek egyesek számára, vagy rövid távon költségeket jelentenek, miközben hosszabb távon hasznosak lehetnek. Számos eset és vizsgálat 
mutatja, hogy az ilyen döntéseket is lehet legitimálni, és ebben a bizalom fontos szerepet játszik.

Vállalati kontextusban kimutatták, hogy a vezetőjük és a szervezetük iránt magas bizalmat tápláló alkalmazottak hitelesebbnek találják a fönöktől származó információkat, komolyabban veszik őket, és a kellemetlen információkat, illetve döntéseket is jobban elfogadják (lásd például Holtz-Harold, 2008).

Amerikai adatokon Marc J. Hetherington (2005) azt bizonyítja be, hogy a politikailag megosztó, társadalmi támogatást kívánó, jelentős újraelosztással járó döntéseket (törvényeket) akkor hozzák meg, amikor a kormányba vetett társadalmi bizalom magasabb - függetlenül attól, hogy melyik pártnak van többsége a törvényhozásban. Hasonló módon érvel Győrffy Dóra (2017) is: szerinte elsősorban a bizalom magyarázza azt, hogy mely európai országokban tudtak rövid távon áldozatokkal járó, de hosszabb távon kedvező hatásúnak bizonyuló gazdaságpolitikai reformokat bevezetni. Mindez tulajdonképpen logikus. Ha a döntéshozó áldozatokat kíván az érintettektől, akkor jobban teszi, ha ennek elkerülhetetlenségéről meggyőzi őket, és/vagy épít a meglévő hitelességére, bizalmi tartalékára. A kettő közül viszont kétségkívül az utóbbi a fontosabb, hiszen ha a döntéshozó hitelességi deficittel küzd, és alacsony iránta a bizalom, akkor félő, hogy a meggyőzésre irányuló érvei sem érnek célt. Ha pedig az érintettek nem fogadják el az áldozathozatal szükségességét, akkor tiltakozásukkal akár meg is hiúsíthatják az adott döntést.

Ugyanakkor a döntéshozók időnként túl könnyen kérnek áldozatot, és javaslataik gyakran vitathatóak. Vagyis meglehet, hogy az érintettek jól teszik, hogy nem bíznak feltétel nélkül a döntéshozóikban. A bizalom és a bizalmatlanság egyensúlyára van szükség: maga a liberális demokrácia, a hatalmi ágak szétválasztása, az alkotmányosság is értelmezhető úgy, mint a bizalmatlanság intézményesítése, amely pont ezáltal teremthet bizalmat. A vállalatok demokratizálása mellett szóló érvek hasonló logikát követnek: a vállalatok úgy igyekeznek kommunikációs eszközökkel bizalmat építeni maguk iránt, hogy ennek többnyire nincsenek meg a morális alapjai, a centralizált és nem átlátható döntéshozatal pedig kockázatos vagy egyenesen költséges következményeket terhel az érintettekre, a fogyasztókra, az alkalmazottakra vagy a természeti környezetre (vö. Zsolnai, 2016).

Az esetek többségében valószínüleg nincs olyan objektív módszer, amellyel eldönthetö lenne, hogy a döntés tényleg megéri-e a rövid távú áldozatot, és valóban előmozdítja-e a kollektív érdeket. Az érintettek tehát minden bizonnyal jól teszik, ha kritikusan viszonyulnak az áldozatot kívánó javaslatokhoz. Az eluralkodó gyanakvás viszont megfojthatja a kollektív cselekvést. Ideális esetben azonban a döntéshozó már korábban bebizonyította, hogy érdemes bízni benne, mert eredményesen és a normatív legitimitás elvárásainak megfelelöen tevékenykedett, és a konkrét esetben is mindent elkövet az eljárási méltányosság tiszteletben tar- 
tásával (például: átlátható döntéshozatallal, beleszólási lehetőség biztosításával), hogy bizalmat ébresszen az adott döntés iránt. A skandináv országok gyakorlata nem áll nagyon messze ettől az ideális képtől, így ott a legnagyobb az esélye annak, hogy rövid távon áldozatot kívánó döntések társadalmi támogatás mellett szülessenek meg (vö. Győrffy, 2017).

\subsection{Gyakorlati együttmúködés és a megvalósitás támogatása}

A döntéseket nem elég meghozni, meg is kell valósítani. A bizalom legfontosabb gyakorlati következménye, hogy megalapozza az együttmüködési hajlamot és elősegíti a kooperációt.

A vállalatok müködésének sikeressége például kritikus mértékben függ a legfontosabb érintett csoportok együttmüködésétől és így a bizalmától (Kramer, 1999). Szükségtelen részletezni, hogy ha a fogyasztók, a befektetők vagy a hitelezők nem bíznak a vállalatban, nem hajlandóak vele együttmüködni (vásárolni a termékeit, finanszírozni a tevékenységét), akkor az akár rövid távon is tönkreteszi a céget. Súlyos nehézségeket okozhat az is, ha az alkalmazottak bizalma, elkötelezettsége inog meg, és elhagyják a szervezetet (nő a fluktuáció), vagy a teljesítmény visszafogásával reagálnak.

Az ellenőrzésen és szankciókon alapuló végrehajtás modellje számos elméleti és gyakorlati problémát vet fel - a leglényegesebb, hogy gyakran nem müködik vagy nem elég hatékony (Boda, 2013, 1. fej.). Ez szervezeti szinten éppúgy igaz, mint közpolitikai szinten. Vállalati szinten nem könnyü az alkalmazottak munkavégzését ellenőrizni, mint ahogy szinte lehetetlen kényszerrel rávenni az állampolgárokat a törvények betartására vagy az adók befizetésére. A kényszerek és az önkéntes motivációk viszonya persze összetett, nem egyszerủen vagy-vagy dilemmáról van szó: például, ha valaki méltányosnak is érzi, hogy adófizetéssel járuljon hozzá a közjavak fenntartásához, azért ugyancsak a méltányosság jegyében gondolhatja, hogy a vonakodókat a hatóságnak kell adófizetésre köteleznie. Mégis, általánosságban igaz az, hogy a döntések megvalósítása könnyebb, ha az érintettek bizalommal és együttműködési készséggel viszonyulnak a megvalósítandó célokhoz.

Számos vizsgálat mutatta ki, hogy a bizalom nemcsak az intézményekkel való együttműködést segíti elö, de vállalati kontextusban is ösztönöz a jobb teljesítményre, a szervezettel való azonosulásra; közpolitikai kontextusban pedig hozzájárul ahhoz, hogy az aktorok (egyének és szervezetek) betartsák a szabályokat, valamint együttmúködjenek a hatóságokkal a közpolitikák végrehajtásában. Hazai mintán kimutattuk, hogy a bizalom az egyik legerősebb faktora az önkéntes adófizetési motivációnak (Bartha-Boda, 2016). 


\subsection{A társadalmi interakciók stabilizálása}

Az intézmények legfontosabb funkciója a társadalmi interakciók stabilizálása, a bizonytalanság csökkentése, a kiszámíthatóság növelése. A bizalom ezzel közvetlen összefüggésben van, hiszen azt mint a jövőre irányuló várakozást definiáltuk. A bizalom hiánya destabilizálja a társadalmi interakciókat, és önbeteljesítő jóslatként müködhet. Például ma Magyarországon a bizalmi válság jelének tekinthetjük, hogy az emberek növekvő mértékben viszik külföldre megtakarításaikat (URL1; URL2), vagy azt, hogy a vállalatok aktuális növekedése elmarad még a potenciálistól is, mert a tulajdonosok haboznak újra befektetni a megtermelt hasznot (Reszegi-Juhász, 2017).

E problémakör tehát messzire vezet: ahhoz a kérdéshez, hogy milyen intézményi elrendezés képes a leginkább csökkenteni a bizonytalanságot a társadalomban, és növelni a bizalmat annak érdekében, hogy a nemzetek ki tudják bontakoztatni fejlödési potenciáljukat. Daron Acemoglu és James A. Robinson (2013) amellett érvel, hogy erre leginkább az úgynevezett „befogadó” intézmények képesek, amelyek biztosítják a vállalkozás szabadságát és a jogbiztonságot. Hasonló problémával foglalkozik, és hasonló eredményre jut a ,jó kormányzás” szakirodalma is, amely szintén arra a meggyőződésre épít, hogy az intézmények minősége meghatározó befolyással van a gazdaság teljesítményére és végső soron a társadalmi fejlödésre.

Az intézményi dizájnnal és annak hitelességével, bizalomra méltóságával kapcsolatos problémák még élesebben merülnek fel az önkéntes együttmüködésen alapuló, többféle (vállalati, civil, állami) aktort magába foglaló „governance” struktúrák kapcsán. Ezek adott esetben hatékonyan képesek megszervezni a társadalmi interakciókat egy problématerületen, de ha a bizalmatlanság aláássa a kooperációt, akkor „béna kacsává” válnak. Jól példázza ezt a Forest Stewardship Council (FSC) és a Marine Stewardship Council (MSC) párhuzamos története (vö. Boda et al., 2009). Mindkét együttmüködési rendszer létrehozásában a WWF (World Wide Fund for Nature) nevü civil szervezet vállalt kezdeményező szerepet, azonban míg az első rövid időn belül számos további partnert bevonva képes lett a fenntartható erdögazdálkodás és fafeldolgozás elveinek és gyakorlatának terjesztésére és hatékony képviseletére, addig a fenntartható halászatot és halgazdálkodást népszerüsítő MSC, elsősorban az Unilever nemzetközi cég befolyásához kapcsolódó hitelességi problémák miatt, sokáig nem tudta együttmüködésre késztetni a legfontosabb érintetteket.

\section{AZ INTÉZMÉNYI BIZALOM GYÖKEREI}

A bizalom kontextusfüggö, komplex és dinamikus jelenség, amely különbözö forrásokból táplálkozhat. Részben racionális, a tapasztalatokon alapuló, részben emocionális jelenség, amely érzékenyen reagál a megbízhatóság vagy megbízhatatlanság jeleire. 
Általánosan elterjedt a vélemény, hogy a bizalom viszonylag stabil jelenség - ez azonban inkább csak a személyközi bizalomra igaz, az intézményi bizalom sokkal volatilisebb. Ugyancsak megfogalmazódtak olyan álláspontok, amelyek szerint a bizalom hosszú távú trendje a fejlett világban csökkenő, és általában könnyebb lerombolni, mint felépíteni. Az adatok mindezt alátámasztják, ugyanakkor fontos megjegyezni, hogy bár történelmi (több évtizedes) távlatban az intézmények iránti bizalom valóban hanyatló pályán van, a bizalom az utóbbi években számos országban stabilizálódott, sőt, növekedésnek indult (vö. Medgyesi-Boda, 2018). A bizalomnak különféle rádiuszai lehetnek. Az interperszonális bizalom esetében például jó eséllyel inkább megbízunk a hozzánk közel álló emberekben, családtagokban, barátokban. Ezt szokás ,partikuláris bizalomnak” nevezni, megkülönböztetve az ismeretlen emberek iránt mutatott „általános bizalomtól”. Van, aki igazából ez utóbbit tekinti a valódi bizalomnak - például Fukuyama a sokat idézett könyvében (Fukuyama, 1997). Magyarország alacsony bizalomszintủ országnak számít, ugyanis az általános bizalom relatíve alacsony, és a bizalom inkább partikuláris viszonyokban érvényesül. Az intézményi bizalom vonatkozásában a rádiusznak talán kisebb a jelentősége, bár a nemzetközivé válással vagy az európai egységesüléssel egyre relevánsabb a kérdés, hogy miként viszonyulunk más országokbeli vagy nemzetközi intézményekhez. A bizalomra különböző tényezők hatnak. Jó okunk van azt feltételezni, hogy a makroszintủ tényezők, így egy adott társadalom kultúrája vagy a társadalmi-gazdasági fejlettsége befolyásolja, hogy egy közösségben mekkora a bizalomra való hajlandóság. Erös az összefüggés az interperszonális és az intézményi bizalom között, ami azt sejteti, hogy van valamilyen közös, például kulturális meghatározottság mögöttük: a bizalom kultúrája és normarendszere érvényesül a személyközi és institucionális viszonyokban is. Ugyancsak erős az összefüggés a bizalom és a kormányzás minőségét (a ,jó kormányzást”, így a jogállam a demokrácia és a korrupciókontroll erősségét), valamint a gazdasági fejlettséget mérő indikátorok között. Ez kiváltképp jellemző az európai fejlődési modellre, amelyben a jóléti mutatók (jövedelmi egyenlőség, társadalmi kohézió, bizalom, az intézmények minősége stb.) erős pozitív összefüggést mutatnak. Hogy mi az ok és mi az okozat, azt nehéz kibogozni, és feltételezhetö, hogy komplex, körkörös összefüggések állnak fenn. Ezért a bizalom növelését is érdemes a társadalmi fejlődés eszközének tekinteni.

Természetesen az egyéni szintü jellemzők is hatással vannak arra, hogy valaki milyen bizalommal él: általánosan megfigyelhető például, hogy a jobb módúak, a tanultabbak vagy az optimista lelkivilágú emberek jobban bíznak az ismeretlen emberekben vagy éppen az intézményekben.

A bizalom azonban részben a bizalom konkrét tárgyához füződő benyomásokon, tapasztalatokon alapszik, ezért a makroszintü összefüggéseken, valamint az egyéni szintủ jellemzőkön túl a bizalom tárgyának észlelt magatartása, müködése is hatással van rá. Ez a mozzanat különösen releváns az intézményi bizalom 
vonatkozásában, hiszen az emberekkel ellentétben állami intézményekhez vagy vállalatokhoz nincsen feltétlenül előre kódolt érzelmi viszonyulásunk. Így a velük kapcsolatos várakozásainkat legalább részben müködésük észlelt jellemzői, illetve az interakciókban kialakult tapasztalat formálja.

Az intézményi müködés vonatkozásában a szakirodalom általában két fő dimenzióra vezeti vissza az intézményi bizalmat: az intézmények észlelt eredményességére, teljesítményére, hatékonyságára, illetve az intézmények müködésével kapcsolatos normatív, etikai elvárásokra (vö. Zsolnai, 2004). Nem tudunk bízni, mondjuk, az adóhatóságban, ha az a benyomásunk, hogy nem végzi megfelelöen a dolgát; nem eredményes; nem professzionális; rossz a teljesítménye. De éppúgy aláássa a bizalmat az az észlelés, hogy az adóhatóság jogsértően müködik; korrupt; munkatársai tiszteletlenül, hatalmukkal visszaélve bánnak az állampolgárokkal, és nem tartják tiszteletben a szakmai és az általános, társadalmi normákat. Ezeket az összefüggéseket nemcsak nemzetközi, de hazai adatok is bizonyítják: kutatásunkban a NAV (Nemzeti Adó- és Vámhivatal) korrupciós botrányának hatását elemeztük a bizalomra, és nem meglepő módon azt találtuk, hogy az állampolgárok érzékenyek a korrupció percepciójára. A korrupció erősségéről alkotott vélemény negatív összefüggésben áll az adóhatóságba vetett bizalommal. A korreláció persze még nem bizonyít okságot, ám a NAV 2014-es korrupciós botránya után szignifikánsan csökkent az adóhatóságba vetett bizalom, miközben más állami intézmények iránt a viszonyulás nem változott - ennek a természetesen kvázi-kísérletnek az eredménye az okságot látszik alátámasztani (Bartha-Boda, 2016).

\section{AZ ELJÁRÁSI MÉLTÁNYOSSÁG ÉS A BIZALOM MORÁLIS ALAPZATA}

Az intézményi bizalomra egyfelől az intézményi eredményesség, a professzionalizmus, a teljesítmény, másfelől az etikai elvek és értékek tiszteletben tartása érdemesít.

A szakirodalomban kiemelt figyelem övezi az eljárási méltányossággal (procedural fairness) kapcsolatos problémákat. Tom R. Tyler empirikus tanulmányok sorozatában bizonyította, hogy az eljárások és a bánásmód etikussága kulcsfontosságú a bizalom és az együttmüködési készség megalapozásában. Ö elsősorban a jogrendszerbe vetett bizalmat kutatta (vö. Tyler, 1990), de számos különböző intézményi kontextusban (szervezeteken belül; vállalatok között; állami intézményekkel kapcsolatban; a nemzetközi diplomáciában) is kimutatták az eljárásokkal kapcsolatos értékelések jelentőségét. A szakirodalom részletes áttekintésére itt nincs mód (erről lásd Boda, 2013), csak arra térünk ki, hogy miként is értelmezhető az eljárási méltányosság, és hogy vajon mivel magyarázható a jelentősége. 
A két kérdés részben összefügg, ugyanis az eljárási méltányosságba sokféle normatív elvárást bele lehet érteni - és ez a jelentőségét is érthetővé teszi. Gerald Leventhal (1980) a méltányos eljárás következő kritériumait sorolja fel: képviselet, részvétel, véleménynyilvánítási lehetőség biztosítása; semlegesség, pártatlanság, elfogulatlanság; a döntések időbeli és elvi konzisztenciája; az egyén státuszának elismerése (egyenlő elbánás, jogok figyelembevétele, respektus); körültekintő, gondos, precíz eljárás, szakszerü döntéshozatal; felülvizsgálati lehetőség, a rossz vagy méltánytalan döntések kijavításának lehetősége; jóindulat; és végül az általános etikai elveknek való megfelelés. Ez utóbbi kritérium azt sugallja, hogy az eljárási méltányosság adott esetben valóban szinte minden etikai normát magában foglalhat.

Vagyis az eljárási méltányosság egyrészt talán azért fontos a bizalom kialakításában, mert bizonyos értelemben általában a normatív elvárások szinonimájaként érthető - de legalábbis azon normatív elvárásokénak, amelyek többé-kevésbé közvetlen kapcsolatban vannak az intézményekkel történő interakciókkal. De további, pszichológiai gyökerü magyarázatok is vannak az eljárási méltányosság jelentőségének megértésére: Kevin B. Smith és szerzőtársai (2007) például úgy érvelnek, hogy a hatalom gyakorlásának alapvető etikai minőségét teszteljük az eljárások értékelésével. Ha a vezető méltánytalanul jár el, akkor ez azt sugallja, hogy hatalmát rosszul használja, és ez gyanakvásra ad okot - ezt, a vezetéssel és a hatalommal kapcsolatos ősi, és alapvetően kritikai attitüdöt vinnénk át az intézményekre is. Más szóval, az eljárási méltányosság közvetlen kapcsolatban lehet az adott intézmény vagy autoritás legitimitásával, habermasi kifejezéssel élve „elismerésre méltóságával”. Mások, így Tyler (1990) is, azt hangoztatják, hogy az eljárások méltányosságának a fö üzenete a respektus: az, hogy elismernek bennünket, és elismerik, hogy ugyanannak a morális közösségnek a részei vagyunk. A méltánytalanság érzete tehát egy nagyon alapvető pszichológiai igényt, a közösséghez tartozásét sérti.

Az eljárási méltányosság fontossága a bizalom kialakításában nehezen vonható kétségbe, hiszen számos, eltérő intézményi kontextusban készült tanulmány bizonyította. Ez különösen figyelemre méltó annak fényében, hogy a legtöbb kutatás az eljárási méltányosságot korántsem a Leventhal által javasolt széles jelentésben, hanem kifejezetten a bánásmódra leszükítve értelmezi és méri. Véleményem szerint ennek az is az oka, hogy ezek a vizsgálatok jellemzően a fejlett demokráciákban készültek, ahol az alapvető értékekben, az érvényes normákban viszonylag széles közmegegyezés van. Ilyen körülmények közepette a bánásmód kiemelt jelentőségre tesz szert. De ez korántsem jelenti azt, hogy egyéb normatív, etikai megfontolásokhoz képest előbbre kellene sorolni: valójában azok is éppen olyan fontosak. És ha az alapvető értékkonszenzus hiányzik, akkor az éppen úgy vagy még jobban akadálya a bizalom létrejöttének. Több kutatás bizonyítja például, hogy a vállalatok müködésének társadalmi, etikai, környezeti hatásai befolyásol- 
ják a fogyasztói bizalmat (például Kang-Hustvedt, 2014), és a legfrissebb adatok szerint világszerte az alkalmazottak is növekvő elvárással fordulnak a vállalatvezetők felé, hogy azok foglaljanak állást társadalmi, etikai kérdésekben (URL3). Vagy visszautalva fentebb idézett kutatásunkra (Bartha-Boda, 2016) az adóhatóságba vetett bizalomról: a korrupció ugyan a leventhali tág definícióba belefér, és értelmezhető eljárási méltányosságként, ugyanakkor lényegét tekintve többröl van szó, mint a bánásmód megítéléséröl. A korrupció alapvetően morális probléma, ami érthető módon aláássa a bizalmat.

Az emberek érzékenysége az eljárási méltányosságra visszaélésekre is alkalmat ad, elfedve a mélyen húzódó esetleges értékkonfliktusokat. Ha egy vállalat fair módon, respektussal stb. bánik fogyasztóival, akkor bizalmat ébreszthet akkor is, ha tevékenysége nem felel meg az alapvető etikai, társadalmi, környezeti normáknak. Nem véletlen, hogy az eljárási méltányosság jelentőségét kimutató kutatások hangsúlyozzák annak gyakorlati implikációit: az eljárások, elbánások és folyamatok viszonylag könnyen megváltoztathatóak, méltányosabbá tehetőek, míg az alapvetó értékválasztások nehezen módosíthatóak. Ez a példa ismét a kritikus bizalom fontosságára mutat rá.

\section{IRODALOM}

Acemoglu, D. - Robinson, J. A. (2013): Miért buknak el nemzetek? A hatalom, a jólét és a szegénység eredete. Budapest: HVG Kiadói Rt.

Bartha A. - Boda Zs. (2016): Adómorál, bizalom és kényszerek - adózási motivációk Magyarországon korrupciós botrányok idején. Közgazdasági Szemle, 53, 10, 1021-1045.

Boda Zs. (2013): Legitimitás, bizalom, együttmüködés: kollektív cselekvés a politikában. Budapest: Argumentum Kiadó

Boda Zs. - O'Higgins, E. - Schedle, K. (2009): Cooperating with civil and political actors. In: Zsolnai L. (ed.): The Future International Manager. Palgrave MacMillan, 130-152.

Fukuyama, F. (1997): Bizalom. A társadalmi erények és a jólét megteremtése. Budapest: Európa Kiadó

Győrffy D. (2017): Bizalom és pénzügyek. Válság és válságkezelés az Európai Unióban. Budapest: Typotex Kiadó

Hardin, R. (1998): Trust in Government. In: Braithwaite, V. - Levi, M. (eds.): Trust and Governance. New York: Russell Sage Foundation, 9-27.

Hetherington, M. J. (2005): Why Trust Matters: Declining Political Trust and The Demise of American Liberalism. Princeton, NJ: Princeton University Press

Holtz, B. C. - Harold, C. M. (2008): When Your Boss Says No! The Effects of Leadership Style and Trust on Employee Reactions to Managerial Explanations. Journal of Occupational and Organizational Psychology, 81, 777-802. DOI: 10.1348/096317907X251569

Kang, J. - Hustvedt, G. (2014): Building Trust Between Consumers and Corporations: The Role of Consumer Perceptions of Transparency and Social Responsibility. Journal of Business Ethics, 125, 2, December 2014, 253-265. DOI: 10.1007/s10551-013-1916-7

Kramer, R. M. (1999): Trust and Distrust in Organizations: Emerging Perspectives, Enduring Questions. Annual Review of Psychology, 50, 569-598. DOI: 10.1146/annurev.psych.50.1.569 
Leventhal, G. (1980): What Should Be Done with Equity Theory? New Approaches to the Study of Fairness in Social Relationships. In: Gergen, K. J. - Greenberg, M. S. - Willis, H. J. (eds.): Social Exchange: Advances in Theory and Research. New York: Plenum, 61-83. DOI: 10.1007/978-1-4613-3087-5_2, https://www.researchgate.net/publication/248426054_What Should_Be_Done_with_Equity_Theory

Medgyesi M. - Boda Zs. (2018): Intézményekbe vetett bizalom Magyarországon és az Európai Unió országaiban. In: Kolosi T. - Tóth I. Gy. (szerk.): Társadalmi riport 2018. Budapest: TÁRKI, http://www.tarki.hu/tarsadalmi-riport

Reszegi L. - Juhász P. (2017): Gátak a magyar vállalati növekedésben. Vezetéstudomány, 18, 6-7, $27-38$.

Smith, K. B. - Larimer, C. W. - Littvay, L. et al. (2007): Evolutionary Theory and Political Leadership: Why Certain People Do Not Trust Decision Makers. The Journal of Politics, 69, 2, 285-299. DOI: 10.1111/j.1468-2508.2007.00532.x, https://www.unl.edu/polphyslab/SmithPolitics.pdf

Tyler, T. R. (1990): Why People Obey the Law. New Haven: Yale University Press

Tyler, T. R. (2011): Why People Cooperate. The Role of Social Motivations. Princeton: Princeton University Press

Zsolnai L. (2004): Honesty and Trust in Economic Relationships. Management Research News, 27, 7, 57-62. http://laszlo-zsolnai.net/content/honesty-and-trust-economic-relationships

Zsolnai L. (2016): The Failure of Business Ethics. Society and Business Review, 11, 1, 93-104.

URL1: http://www.vg.hu/penzugy/megtakaritas/egyre-tobb-penzt-tartanak-kulfoldon-a-magyarok-461996

URL2: http://www.azenpenzem.hu/cikkek/ezermilliardokat-tart-a-magyar-lakossag-kulfoldon/3130/

URL3: https://www.edelman.com/post/trust-barometer-expectations-for-ceos 